\title{
Forests and Stream Flow
}

$\mathrm{T}$ HE effect of the action of forests in conserving water supplies and regulating the flow of water in streams and rivers, whilst preventing erosion in mountainous countries with consequent disastrous floods, has been under discussion for several centuries. Attention was directed to this important matter in an article entitled "Forests, Climate, Erosion, and Denudations" in NATURE of April 4, 1931. The opinions commonly accepted by foresters and many engineers are to the effect that forests are beneficial (1) by retaining and storing water in the humus layer on the forest floor and allowing it to percolate gradually into springs and streams, thus retarding a rapid runoff ; (2) retarding the melting of snow in the spring and thus prolonging the run-off from this source ; (3) increasing precipitation ; (4) preventing erosion on steep slopes. It may be admitted that direct proof of the actual effect of disafforestation of the catchment area of a river on the future water level of that river based on a prolonged series of measurements, has been so far wanting. But the ultimate results, both to the catchment area and the plains country below should reafforestation not take place, cannot be called in question. Europe itself, along the shores of the Mediterranean, and many parts of India offer numerous illustrations of the aftermath of reckless forest denudation, followed by the drying up of water supplies.

In a paper entitled "Forests and Stream Flow" delivered before the American Society of Civil Engineers at its annual convention in Yellowstone Park on July 6, 1932, Messrs. W. G. Hoyt and H. C. Troxall call in question, from the engineers' point of view, the usefulness of forests in maintaining and regulating water supplies. They base their conclusions on the following. An experiment by the United States Forest Service and the U.S. Weather Bureau was conducted from 1910 until 1926 on two contiguous tracts of land in Southern Colorado (Wagonwheel Gap area) of 222.5 and $200 \cdot 4$ acres respectively, having almost identical geographical, topographical and meteorological conditions. The forest cover in both areas was representative of the Rocky Mountain area as a whole. In 1919 the smaller area was disafforested and the slash burnt in 1921. By 1926 the area had become recovered by a growth of grass, herbs and aspen shoots which had reached a height of three to six feet. Throughout the period, accurate measurements of the run-off and meteorological observations were recorded.

A distinct investigation on stream-flow measurements was begun in 1916 under the auspices of the U.S. Geological Survey, in co-operation with the State of California and the County of Los Angeles on certain areas in California. In August 1924 a forest fire burnt some of the areas under observation, and one of them, Fish Creek, was selected to establish the effect of the fire and resulting disafforestation on the discharge of this creek. A new growth appeared over the area burnt, and by the autumn of 1930 it is said that little evidence of the fire remained, though a different plant association had developed.

The investigations recorded by the authors, and the deductions therefrom, are therefore based in the first case on the observations of seven years (1920-1926) and in the second on six years (19251930). It is impossible to do more than glance at the conclusions arrived at from the records and data, which are most ably dealt with in this monograph. They are, however, sufficiently startling to require more detailed investigations on the same lines and will merit careful consideration in many parts of the British Empire where forests, agriculture and commercial interests are so inextricably interwoven. Briefly, the authors hold that forests do not conserve the water supply; that the increase of run-off is not confined wholly to flood periods; that after disafforestation in the Wagonwheel area there was an increase of forty-six per cent in maximum daily discharge; that the belief that forests or vegetation covering will increase the summer runoff and shorten the low-level period through the exercise of storage functions is a fallacy, so far as the records on the two above widely differing areas are concerned. Further, that coincident with the increase in the summer run-off there was an increase in the average summer minimum and the period of low water run-off was considerably shortened; disafforestation made no appreciable change in the low flows which occurred during the winter in the Wagonwheel area.

The authors, who are hydraulic engineers, state that they are lovers of the forest, but in the interest of water supplies and the maintenance of water supply levels, they consider that "If the small growth that springs up immediately after disafforestation" (though this is not the case in all countries) "or denudation exercises practically the same effect as forests in reducing normal flood crests and in preventing erosion without the detrimental effect which forest cover is shown to have on annual flow and flow during the summer low-water periods-then in basins where shortages in water supply are becoming critical or where abnormal expenditures have to be made to augment water supplies, the maintenance of forests or reafforestation for the 'conservation of water supply' may have an effect exactly opposite to that desired."

The investigations, which have been carried out in so liberal a spirit by the United States, are of the greatest importance; and they certainly put a question mark to assumptions which have long been held. It is, however, difficult to believe that foresters and many others who have studied this matter will be able to accept all the deductions of the authors when they are based on records of so short a period as six to seven years.

No. 3293, VoL. 130] 